\begin{tabular}{ll}
\hline 臨 & 床 \\
\hline
\end{tabular}

めまいを早期症状とする多発性硬化症 3 症例

\author{
小山内龍一 ${ }^{1)} \cdot$ 喜多村 健 $^{2)}$

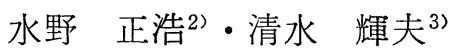

\title{
Neuro-Otological Findings in Three Cases of Multiple Sclerosis Presenting with Vertigo or Dysequilibrium as an Early Symptom
}

\author{
Ryuichi Osanai \\ (Tokyo Metropolitan Neurological Hospital) \\ Ken Kitamura, Masahiro Mizuno and Teruo Simizu \\ (University of Tokyo)
}

1. Three patients with multiple sclerosis presented with vertigo or dysequilibrium as an early symptom.

2. Neurootological examination showed abnormal findings in all three cases.

3. Gaze nystagmui, direction-changing positional nystagmus, rebound positional nystagmus and vertical positioning nystagmus were observed in these patients, indicating a disturbance of the central vestibular system.

4. MLF (medial longitudinal fasciculus) syndrome, indicating a brainstem lesion, was present in two patients.

5. Caloric testing was performed in two patients. The duration and the slow phase velocity of the caloric-induced nystagmus were within normal limits, while visual suppression of the caloric-induced nystagmus was impaired in both patients.

6. The optokinetic nystagmus pattern test was performed in two patients. The optokinetic nystagmus was markedly depressed when the patients first visited the vestibular clinic shortly after the onset of the vertiginous attack. It gradually improved towards normal during the course of the disease in close correlation with recovery from other neurological signs and symptoms.

Key words: multiple sclerosis, vertigo, dysequilibrium, neurootological findings, electro-nystagmography

1）東京都立神経病院神経耳科

2) 東京大学医学部耳鼻咽喉科学教室

3) 東京大学医学部脳研神経内科学教室 
はじめに

多発性硬化症は原因不明の脱髄性疾患であ り，中枢神経系に病巣が散在していることと， 神経症状が再発・再燃を繰返すととを特徵とし ている．経過中に眼振が認められるのは症例の 24\%から 60\% と報告されているが市 4)，初発症 状としては視力障害，四肢のしびれ感，運動麻 㿁などが多く，めまいを初発症状とする症例は 比較的少ないといわれている(1) 46). 今回我々 はめまい・平衡障害を主訴あるいは初発症状と し，多発性硬化症が疑われた 3 症例を経験した ので，その神経耳科学的所見について報告す る.

\section{症例 $1 \square$ 初部時年齢22歳 女}

主訴 : 回転性めまい

既往歴・家族歴：特記すべきととなし.

現病歴ならびに臨床経過：1972年1月 8 日,パ 一マから帰ってくるときに，めまいを自覚した. 地面が摇れる感じがして歩きにくかった． 3 〜 4 日間乙の歩行時のめまいは持続した。 1 月12 日朝，目がさめたとき嘔吐をともなう回転性め まい発作が生じた。難聴・耳鳴・意識障害は自
覚しなかった。 2 月 7 日, 東京大学附属病院耳 鼻咽喉科初診。2月21日頃にはめまいの自覚は ほとんどなくなった。1973年 4 月より四肢失調 を指摘されており，1976年頃から痙性・失調性 の歩行障害が明らかとなってきた。 歩行障害は 一時期軽快したが全体的にみれば徐々に悪化し た.1977年頃から痴呆が生じ, 徐々に進行した。 1979年に右視力低下が括こったがステロイド療 法をうけてまもなく回復した。1982年には尿失 禁が生じた。1982 年11月18日，都立神経病院 神経内科に入院しステロイド療法，続いて $\mathrm{ACTH}$ 療法をうけたが症状に著明な変化なく, 免疫抑制剂の投与により歩行がやや安定し， 1983年 6 月11日退院した。全臨床経過をまとめ て図 1 に示した.

神経学的所見：1982年11月18日の都立神経病 院入院時の一般神経学的所見として，1）痴呆, 2 ）軽度の右片麻痺，3）四肢失調，4）断経 性緩徐言語，5）痙性失調性歩行，6）尿失禁, を認めた，知覚障害を認めず，眼底は正常で，

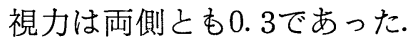

神経耳科学的所見：1972年 2 月 7 日，1982年 11月26日とも, 耳鼻咽喉鏡所見に異常なく，純

\subsection{2月 \\ 回転性めまい} 歩行障害

1973頃四肢失調

\subsection{1月痤性・失調性歩行}

\section{7頃}

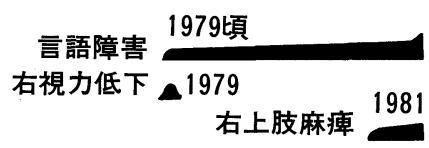

尿失禁 1982

1972.2.7
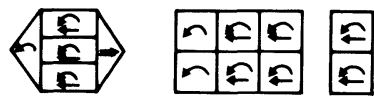

1982.11 .26

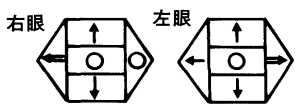

2.21
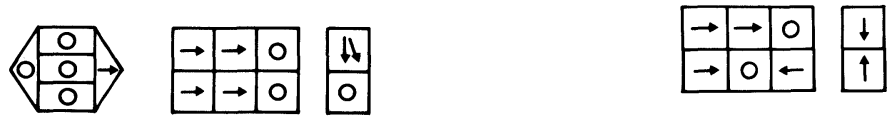

図 1 症例 1 の臨床経過と眼振所見 
音聴力は正常であった．1972年 2 月 7 日には左 右注視眼振と右向きの方向固定性水平回旋混合 性頭位眼振がみられたが，2 月21日には注視眼 振は左注視時に認められるのみとなり，頭位眼 振も左向きに変化した(図 1 ). 発症約 1 年後の 1973年 4 月には両側 MLF 症候群が出現し, そ の後の経過中も同様の所見が得られた(図 2 ). 発症約10年後の1982年11月26日には完全注視方 向性眼振之方向交代性上向性頭位眼振が観察さ れ，頭位変換眼振検查により垂直性眼振が誘 発された(図 1)。温度眼振検査では，1972年， 1982年ともに，両耳とも反応時間は正常であっ たが，1982年の検査では温度眼振の視性抑制が 両側と屯低下していた。1973年 4 月および1982 年11月29日ともに，視標追跡検査は右眼・左眼 とあ外転時に眼振が重畳するパターンを示し， 衝動性眼球 運動は，右眼・左眼とも内転速度 の低下を示した。視運動性眼振 (optokinetic nystagmus; OKP 法による) は発症直後の1972 年 2 月 7 日には解発不良であったが，めまいの 軽快にとあなって同年 3 月 6 日には OKP あ著 明な改善を示した(図 3 ). 神経学的な諸症状の 悪化がみられた発症10年後の1982年11月29日に は OKP は高度の異常を示し，ACTH 療法や 免疫抑制療法にもかかわらず，半年後の1983年 5 月20日の再検査時にも OKP は著明に障害さ れたままであった。

本症例は病巣が大脳・脳幹・小脳・脊逞・視 神経に散在しており, 症状の寛解・増悪があり， 他疾患を示唆する所見のないととから，多発性 硬化症と診断された.

\section{症例 2 初診時年齿15歳 男}

主訴：ふらつき

既往歴・家族歷：特記すべきととなし

現病歷：1983年 5 月 27 日, 朝 6 時に起床して から左右のふらつきを自覚した，翌日にはふら

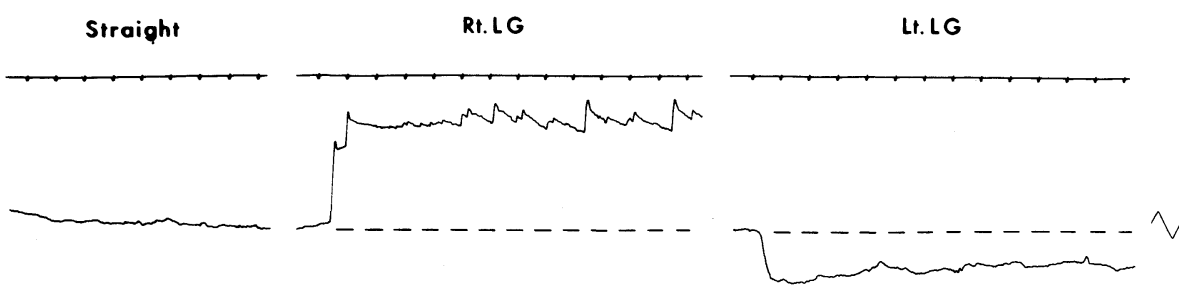

OD

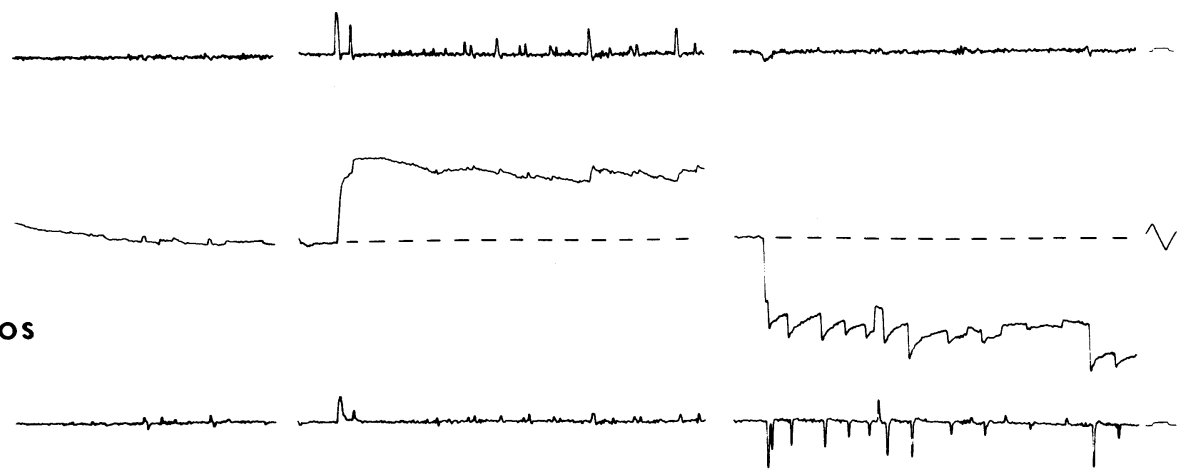

図 2 症例 1 の眼球運動記録

両側内転眼の速度低下と両側外転眼の単眼性眼振か認められ，両側 MLF 症 候群の存在がみられる。

Rt.LG : 右 $30^{\circ}$ 注視, Lt.LG : 左 $30^{\circ}$ 注視. 較正は原波形は $10^{\circ}$, 微分波形 は $20^{\circ} / \mathrm{s}$ (以下の記録も同様). 
つきが増強した，側方注視をすると像がゆがん で見えた. 6 月 1 日某大学眼科受診, 眼科的異 常なしと診断された。 6 月 2 日自治医科大学耳 鼻科初診.

神経学的所見：1）両側四肢深部反射六進 之, 2 ) 両側 $\mathrm{Th}_{7,8}$ 以下の表在知覚低下を認め た. 四肢失調は認めなかった。

神経耳科学的所見：聴力は正常であった．両 眼内転障害, 左眼外転障害があり，右注視時に 右眼の単眼性眼振を認めた。輻輳は右眼の内転 が制限されていたが左眼は良好であった。頭位

・頭位変換眼振は認めなかった(図 4).

本症例の眼球運動所見は，(1)両側 MLF 症候 群十左外転神経麻痺とも, (2)左 PPRF (paramedian zone of the pontine reticular formation)
障害十左 MLF 症候群（すなわち one-and-half syndrome）とも考えられるが，いずれにせよ，

\section{右 眼}
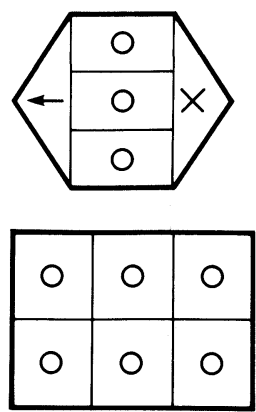

図 4-a 症例 2 の眼球運動および眼振所見 右眼の内転障害と外転時の単眼性眼振があり, 左眼は内転・外転ともに障害されていた，頭位お よび頭位変換眼振は認めなかった。
左 眼

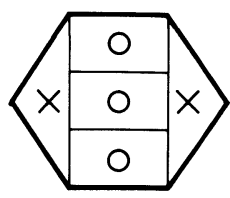
Rt. OKP
Lt. OKP

A

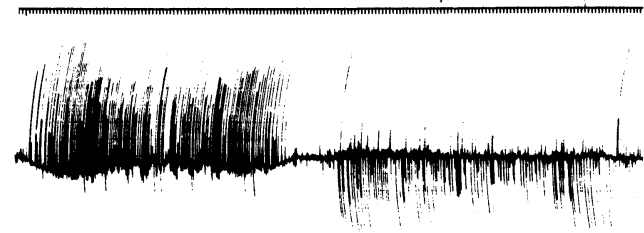

2.7

B

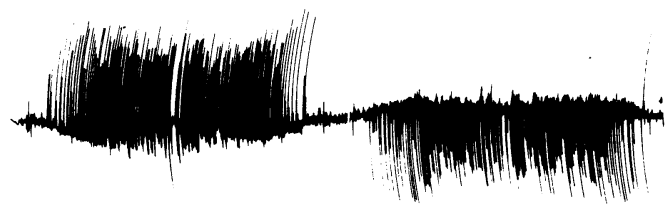

2.21

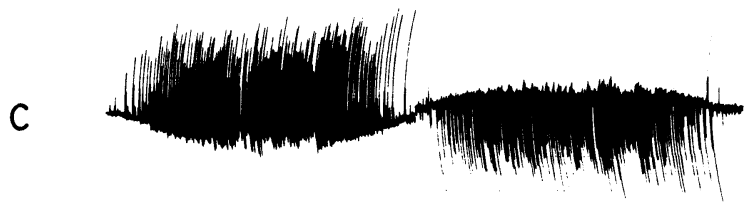

3.6

図 3 症例 1 の視運動性眼振 (OKP)

発症直後の1972年 2 月 7 日には両側 OKP の高度の障害が認められたが，めま いの軽快にともなって OKP 屯著明に改善した。 
左に強い橋被蓋の障害を示すあのである，本症 例ではさらに錐体路障害および脊髄障害を認め た．神経症状の出現は 1 回のみであるが，病巣 の多巣性があり, 多発性硬化症疑い例之考えら れる。

\section{症例 $3 \square$ 初診時年齢46歳 女}

主訴：ふらつき，しびれ感

既往歴：特記すべきととなし

家族歴 : 父親; 胃癌. 姉; リウマチ様関節炎.

現病歴：1986年10月から11月末にかけて間 歇的に熱発があり，11月18日から右肩に激痛が 生じたが 1 週間で軽快した。12月15日頃ふらつ きが生じ，12月24日頃全身のしびれ感と右方視 のさいの動摇視が生じ，12月29日頃には右方へ の偏倚傾向が明らかとなり歩行不能となったた め, 同日某院に入院した. 1987年 1 月 2 日から
11日までステロイド療法をうけ，1月12日頃よ り歩行は徐々に回復した。 1 月16日東大病院神 経内科に入院した。

神経学的所見（1987年 1 月 16日)：1）歩行 時の右方への転倒傾向，2）右向き水平回旋混 合性眼振，3）四肢拄よび乳頭より下の体幹の dysesthesia を認めた。

神経耳科学的所見(図 5)：1月19日には正面 ・上方・下方および右方注視時に右向き水平回 旋混合性眼振之右向きの方向固定性頭位眼振が あり，右下頭位から正面に戻したときには左向 きの rebound positional nystagmus が認められ た，坐位から㲘垂頭位にするさい左向き水平回 旋混合性眼振が認められた。 2 月13日には眼振 は主に回旋性となり，3月 6 日には頭位・頭位 変換眼振は不明瞭となっていた，視標追跡検査

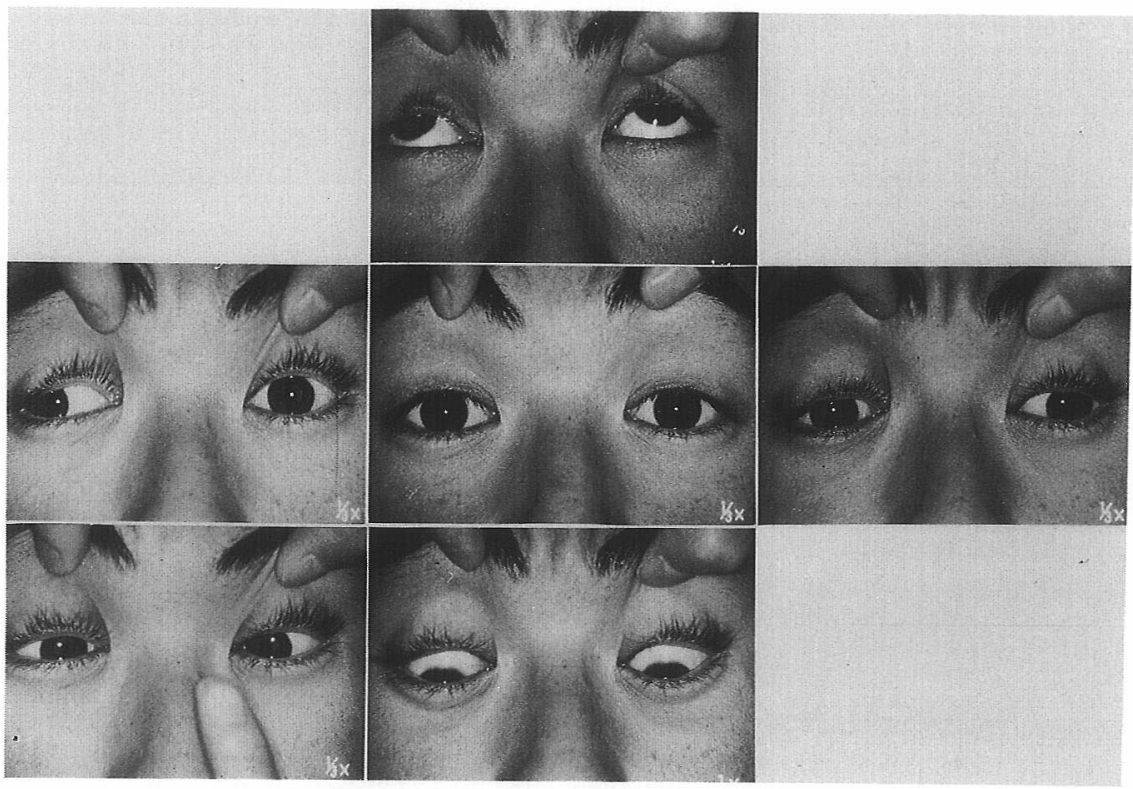

図 4-b 症例 2 の眼球運動の可動域

\begin{tabular}{|c|c|c|}
\hline & 上方注 視 & \\
\hline 右方 注 視 & 正面 注 視 & 左方注 視 \\
\hline 輻 & 下方 注 視 & \\
\hline
\end{tabular}


1987. 1.19.
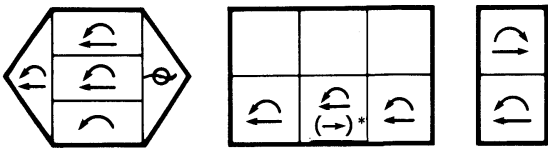

1987. 2.13.

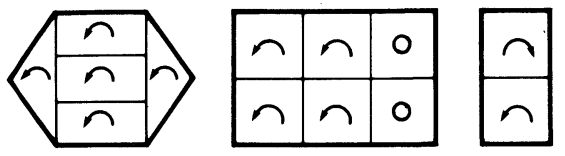

1987. 3. 6 .
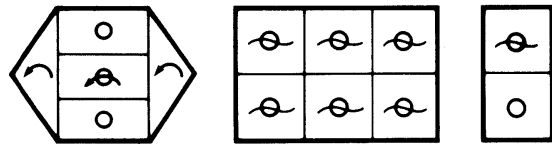

図 5-a 症例 3 の眼振所見

1987年 1 月19日には，右下頭位から正面位に㞍した とき，左向きの rebound positional nystagmus を認 めた（*). 3 月 6 日には認められなくなった。
は軽度階段状で，衝動性眼球軍動検査は水平方 向の注視点変換時に著明な dysmetria がみられ た. 1 月27日には OKP の異常が著明であった が 2 月20日および 3 月18日には改善を認め， 6 月17日にはさらに改善していた。 しかし，眼振 頻度および最大緩徐相速度の軽度の低下は残存 した (図6). 温度眼振反応は両側正常であった が，視性抑制は 1 月末で右向き眼振に対して10 $\%$,左向き眼振に対して $30 \%$ と障害されていた.

3 月18日には左向き眼振に対する視性抑制は50 \%程度と改善を示したが右向き眼振に対しては $0 \%$ あった。 6 月17日には右向き眼振に対し て40\%，左向き眼振に対して50\%であった.

本症例は神経耳科学的所見加ら前庭小脳, 小 脳正中部，ないし前庭神経核の障害などが想定 され，MRI で脳幹に病変が確認された(図 7 ). その上，泰䯣障害も存在すると考えられ，多発 性硬化症疑い例である。
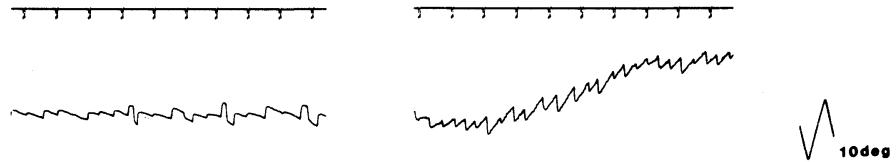

HORIZONTAL

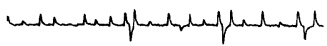

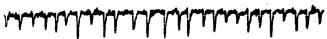

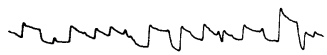

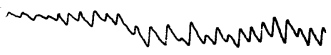

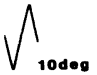

\section{VERTICAL}

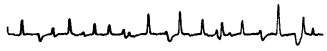

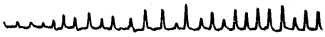

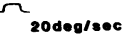

\section{SITTING}

\section{SUPINE,HEAD DOWN}

図 5-b 症例 3 の ENG（1987年 1月27日）

最上段は 1 秒の時標. $2 \cdot 3$ 段目は水平誘導. $4 \cdot 5$ 段目は垂直誘導. 左は坐 位・正面注視. 右は仰臥位・懸垂頭位. 坐位では右向き，仰臥位・䀣垂頭位では 左向きの眼振が記録されており，いずれも回旋成分を伴っている. 
考察

多発性硬化症の神経学的所見は錐体路症状, 視力低下, 失調・企図振戦, 顔面神経麻痺, 眼 振, 眼筋麻痺, 構語障害など, きわめて多岐に

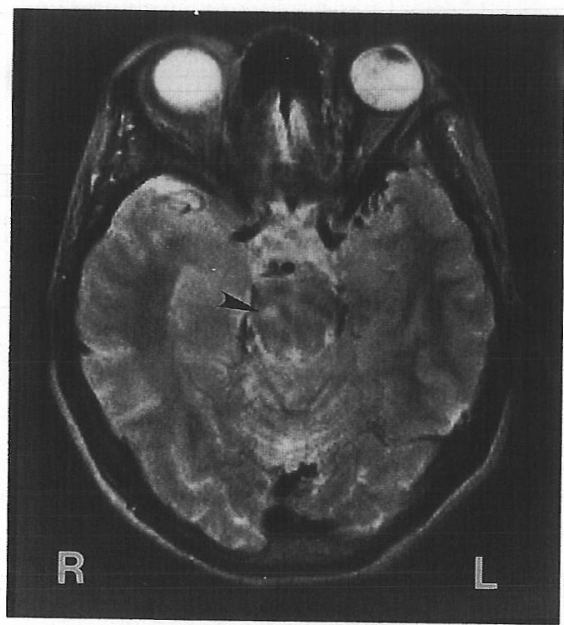

図 7 症例 3 の MRI

$\mathrm{T}_{2}$ 強調像 $(\mathrm{TR}=2000 \mathrm{msec}, \mathrm{TE}=75 \mathrm{msec})$. 橋の右 側に高信号域が認められる (矢印)。1 1987 年 2 月21日 施行.
わたっている(1) 3) . 多数例の多発性硬化症の 神経耳科学的所見については Dayal ら(1966) ${ }^{7)}$, Noffsinger ら $(1972)^{8)}$, Aantaa $(1973)^{2)}$, Grénman (1985)9) の報告がある(表 1 ). 表に示 したように，視標追跡検査・衝動性眼球運動検 査・視運動性眼振の障害をはじめ, 自発・頭位 眼振, MLF 症候群, 温度眼振の視性抑制の障 害などの, 中枢障害を示唆する所見が報告され ている．とくに前 3 者の異常が全症例の半数以 上に認められるのが注目される. Harrison ら ${ }^{10}$ によれば，頭位眼振を呈した 461 例の患者の中 に多発性硬化症が 4 例あったが，との 4 例はい ずれあ中枢性（持続性）の頭位眼振を示したと いう. 両側 MLF 症候群は多発性硬化症による ことが多いといわ的ている. Grénman9) は本症 例の ENG 検査を全例単眼誘導で行なってお り，衝動性眼球運動検查時の外転眼之内転眼の 運動状態（速度低下, dysmetria）の相違を示し ている。側方注視時に内転眼の可動域制限がな い場合でも，内転速度の低下という形で MLF 症候群が確認されるととがあり，本疾患ではと

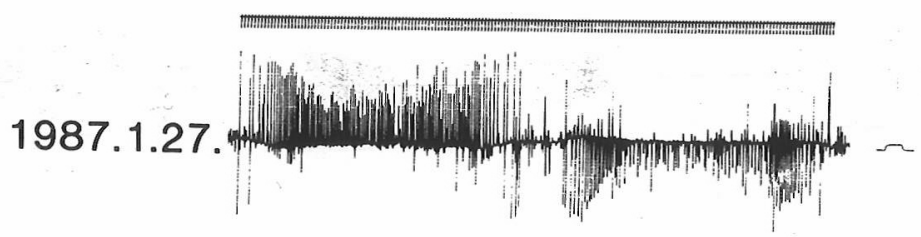

3. 18.

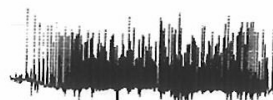

luntont

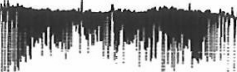

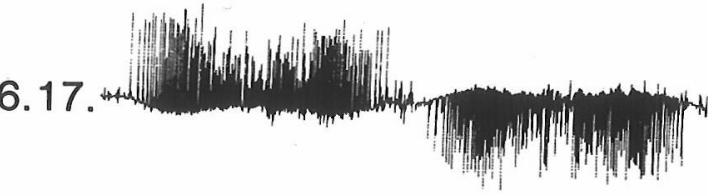

R OKP

図 6 症例 3 の視運動性眼振 (OKP) ふらつきの軽快に伴って OKP 改善傾向を示した。 
くに単眼誘導で ENG を行う必要がある.

我々の症例では, 症例 1,2 で MLF 症候群 が，症例 $1 ， 3$ で注視，頭位，および頭位変換 眼振が認められた．眼振は時期により様相が異 なったが，注視方向性眼振，万向交代性上向性 頭位眼振, 垂直性頭位変換眼振, rebound positional nystagmus ぼ，中枢障害を示す眼振が みられた。症例 2 では右方注視眼振のみ認めら れた. 症例 1，3では両側 OKP の異常がみら れ，めまい・ふらつき，眼振，その他の神経症 状の改善にとあなって OKP あ改善したが, 症 例 1 では発病10年後の症状増覀期には OKP は 障害されたままで，治療によってもあはや改善 を示さなかった，症例 1 では四肢失調・痴呆・ 片麻痺等の症状は全経過中，明らかな改善を示
さず次第に悪化していったが，初発症状である めまい発作は神経耳科学的所見加らは中枢性の あのであり，明らかな改善が認められたこのの ように，本症例では，中枢神経症状の寛解増悪 の存在を神経耳科学的所見から示すととがで き，臨床診断に大きく寄与することができた。 症例 1 および 3 では温度眼振の視性抑制の障害 がみられたが，温度眼振そのあのは正常であ り，少なくとも末梢前庭機能には大きな異常は ないあのと考えられた。

多発性硬化症全体の中で，めまいで発症する あのは比較的少なく，10\%ないしそれ以下とさ れている(1) 6). しかし時にはめまいを主訴な いし早期症状として受診する症例あある ${ }^{11)}$ (18). しかし，めまい・平衡障害を主訴とした多発性

表 1 多発性硬化症の神経耳科学的所見に関する主な報告

\begin{tabular}{|c|c|c|c|c|}
\hline & $\begin{array}{l}\text { Dayal, et al }{ }^{7)} \\
1966(\mathrm{~N}=17)\end{array}$ & $\begin{array}{l}\text { Noffsinger, et } \\
\mathrm{al}^{8)} 1972\end{array}$ & $\begin{array}{c}\text { Aantaa }^{2)} \\
1973(\mathrm{~N}=50)\end{array}$ & $\begin{array}{c}\text { Grénman's) } \\
1985(\mathrm{~N}=70)\end{array}$ \\
\hline MLF 症 候 群 & $5.9 \%$ & $\begin{array}{c}54 \% \\
(N=61)\end{array}$ & $54 \%$ & $\left.\begin{array}{rrr}\text { 軽 } & \text { 度 } & 20 \% \\
\text { 中～高度 } 22.9 \%\end{array}\right] 42.9$ \\
\hline 自 発 眼 振 & $52.9 \%$ & 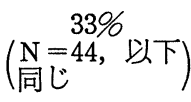 & $34 \%$ & $27.1 \%$ \\
\hline 注 視 眼 振 & $41.2 \%$ & & & $44.3 \%$ \\
\hline 頭 位 眼 振 & $35.3 \%$ & $50 \%$ & $32 \%$ & $\begin{array}{ll}\text { 仰 臥 位 } & 27.1 \% \\
\text { 右下頭位 } & 32.9 \% \\
\text { 左下頭位 } & 32.9 \%\end{array}$ \\
\hline $\begin{array}{l}\text { 視標追跡検査の } \\
\text { 異常 }\end{array}$ & & $55 \%$ & & $\left.\begin{array}{ll}\text { 軽度 } & 42.9 \% \\
\text { 高度 } & 52.9 \%\end{array}\right] 95.7 \%$ \\
\hline 衝動性眼球運動 & & & & $\begin{array}{ll}\text { 潜時延長 } & 35.7 \% \\
\text { 速度低下 } & 67.1 \% \\
\text { dysmetria } & 44.3 \%\end{array}$ \\
\hline $\begin{array}{l}\text { 視運動性眼振の } \\
\text { 䔬常 }\end{array}$ & & $55 \%$ & & $58 \%$ \\
\hline 温度眼振反応の & & $41 \%$ & $36 \%$ & $10 \%$ \\
\hline $\begin{array}{l}\text { 温度眼振の視性 } \\
\text { 制の低下 }\end{array}$ & & $41 \%$ & $44 \%$ & $\begin{array}{ll}\text { 右耳冷水 } & 33.9 \% \\
\text { 左耳冷水 } & 23.9 \% \\
\text { 右耳温水 } & 33.3 \% \\
\text { 左耳温水 } & 30.4 \%\end{array}$ \\
\hline
\end{tabular}


硬化症患者の剖検報告は我々が検索し得た範囲 内では見出すととができず，明らかな責任病巣 は同定されていない。 徳永ら ${ }^{11)}$, Molteni ${ }^{12)}$, Katsarkas $^{13)}$ ，村井ら ${ }^{14)}$ は，いずれもめまい・ 平衡障害を主訴とした多発性硬化症症例を報告 し，障害部位として脳幹を含む中枢神経系の各 部位を想定している.

一方, CT 検査において村井ら ${ }^{14)}$, 横田ら ${ }^{17)}$, 馬塲ら ${ }^{18)}$ のぬい・平衡障害を伴った症例で は異常所見はなかったという.しかし，CT 所 見と剖検所見とを比較した Haughton ら ${ }^{19)}$ の 研究によれば, $0.7 \mathrm{~cm}$ 以下の小さな脱䯣病変 は CT では検出できないといわれ，また，後頭
蓋窩では骨による artifact が混入しやすいとと から, めまいを訴える多発性硬化症患者の病巣 の検出には CT では限界がある.

これに対して MRI（核磁気共鳴像, nuclear magnetic resonance imaging) 検査は骨による artifact が少なく，てれらの患者の病巣の検出 に有用之考えられる. 本症例の MRI で見られ た脳幹の異常所見がめまいの責任病巣であると 断定することはあちろんできないが，表 2 にめ まいを主訴とした多発性硬化症症例のうち， MRI で異常所見の認められたものを自験例を 含めて示した. 4 症例とも脳幹に異常所見を認

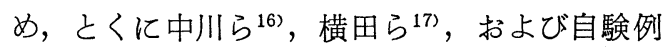

表 2 めまいを主訴とした多発性硬化症の報告例一MRI 所見との関連

\begin{tabular}{|c|c|c|c|c|}
\hline 報 告 者, 年 & 服部ら ${ }^{15)}, 1987$ & 中川ら ${ }^{16)}, 1987$ & 横田ら ${ }^{17)}, 1987$ & 本報告（症例 3 ） \\
\hline 齢, & 46歳, 男 & 25歳, 女 & 25歳, 女 & 46歳, 女 \\
\hline 訴 & $\begin{array}{llll}\text { め } & \text { ま } & \text { い } \\
\text { 左 } & \text { 難 } & \text { 聴・耳 } & \text { 鳴 }\end{array}$ & $\begin{array}{l}\text { 歩行時のふらつき } \\
\text { 頭 痛・嘔 気 }\end{array}$ & $\begin{array}{l}\text { めま い・複 視 } \\
\text { 左顔面神経麻痺 } \\
\text { び れ 感 }\end{array}$ & $\begin{array}{llll}\text { ふ } & ら & \supset & き \\
\text { し } & \text { び } & \text { れ } & \text { 感 }\end{array}$ \\
\hline $\begin{array}{l}\text { 初診時の神経耳科学 } \\
\text { 的所見 }\end{array}$ & $\begin{array}{llll}\text { 左 } & & & \text { 龍 } \\
\text { 眼 振 な } & \text { し }\end{array}$ & 左 右 注 視 眼 振 & $\begin{array}{l}\text { 左右および上方注視 } \\
\text { 輻 輳 眼 振 } \\
\text { ETTとOKN の障害 } \\
\text { 左眼に反跳 眼 振 }\end{array}$ & $\begin{array}{l}\text { 右向き自発眼振 } \\
\text { rebound positional } \\
\text { nystagmus } \\
\text { ETTと OKN の障 } \\
\text { 害, VS の低下 }\end{array}$ \\
\hline $\begin{array}{l}\text { その他の神経学的所 } \\
\text { 見 (経過中) }\end{array}$ & $\begin{array}{l}\text { 左 視 力 障 害 } \\
\text { 左VII, } \mathrm{X}, \mathrm{X} \text { 脳神経 } \\
\text { 障害 }\end{array}$ & $\begin{array}{l}\text { 左 視 力 障 害 } \\
\text { 両側 MLF 症候群 } \\
\text { 両側VI, VII脳神経障 } \\
\text { 害 } \\
\text { 顔面を含む左半身の } \\
\text { 知覚低 }\end{array}$ & $\begin{array}{l}\text { 右 II, 左 I, II, V } \\
\sim \text { X脳神経障害 }\end{array}$ & $\begin{array}{l}\text { 右方への転倒傾向 } \\
\text { 四肢・体幹 (乳頭よ } \\
\text { り市)の dysesthesia }\end{array}$ \\
\hline $\begin{array}{l}\text { 臨床症状から推定さ } \\
\text { れる障害部位 }\end{array}$ & $\begin{array}{lll}\text { 視 } & \text { 神 } & \text { 経 } \\
\text { 脳 } & & \text { 幹 }\end{array}$ & $\begin{array}{lll}\text { 視 } & \text { 神 } & \text { 経 } \\
\text { 脳 } & & \text { 幹 }\end{array}$ & $\begin{array}{lll}\text { 視 } & \text { 神 } & \text { 経 } \\
\text { 脳 } & & \text { 幹 }\end{array}$ & 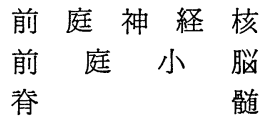 \\
\hline CT 所見 & （記 載 な し） & （記 載 な し） & 異常所見なし & 異常所見なし \\
\hline MRI 所見 & 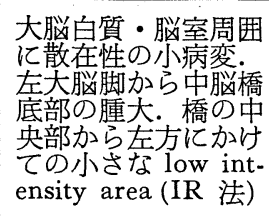 & $\begin{array}{l}\text { 橋背側 ・ 延髄の正中 } \\
\text { 部 high intensity } \\
\text { lesion ( } T_{2} \text { 強調像) }\end{array}$ & $\begin{array}{l}\text { 左橋～延顝背外側部 } \\
\text { 飞病変. }\end{array}$ & $\begin{array}{l}\text { 脳幹の low }\left(\mathrm{T}_{1} \text { 強調 }\right. \\
\text { 像), high ( } \mathrm{T}_{2} \text { 強調 } \\
\text { 像) intensity lesion }\end{array}$ \\
\hline
\end{tabular}

ETT : 視標追跡検査. OKN : 視運動性眼振. IR : inversion recovery. VS : 温度眼振の視性抑制. 
(図 7 )で橋から延䯣にかけての部位に異常所見 が認められたととが注目される。なお，馬塲 $弓^{18)}$ の多発性硬化症疑 (症例は 臨床症状から 延䯣外側部之前庭小脳の障害が示唆されたが, CT および MRI では異常所見は見出されなか ったという．著者が考察で述べているようにこ れは撮影の時期の問題か，あるいは病巣が微小 であったためと思われる。

\section{結語}

1. めまい・平衡障害を主訴あるいは初発症 状とし，多発性硬化症が疑われた 3 症例を報告 した。

2. 側方注視眼振, 方向交代性頭位眼振, rebound positional nystagmus, 垂直性頭位変換 眼振などの，中枢前庭障害を示す眼振所見を全 例に認めた。

3. MLF 症候群や外転神経麻痺などの脳幹 障害の所見が認められた。

4. 視運動性眼振の障害が認められ，病勢を 良く反映していた。

5. 1 例において MRI 検査で脳幹に異常所 見を認めた。

6. 多発性硬化症の患者がめまい・平衡障害 を主訴ないし初発症状として耳鼻科外来を受診 する場合があり，注意が必要と考えられた。

御校閲いただいた東京大学医学部耳鼻咽喉科学教室 野村恭也教授に深謝する。

本論文の要旨は1987年 5 月15日, 第88回日本耳鼻咽 喉科学会総会 (東京) においてロ演した.

\section{文献}

1) Kuroiwa $Y$ and Shibasaki $\mathrm{H}$ : Clinical studies of multiple sclerosis in Japan. Neurology (Minneap) $23: 609 \sim 617,1973$.

2) Aantaa $E$, et al : Electronystagmographic findings in multiple sclerosis. Acta Otolaryngol (Stockh) $75: 1 \sim 5,1973$.

3) 里吉営二郎, 佐久 昭: 多発性硬化症. 現代精神 医学体系（懸田克躬編）13巻, B, 器質精神病. 49 71頁, 中山書店, 東京, 1975.

4) Tsubaki $T$, et al : Clinical and immunologic studies on multiple sclerosis. Neurology (Minneap) 26(6, Part 2):35 36, 1976.
5 ) Adams DK, et al : Early clinical manifestations of disseminated sclerosis. Br Med J 2 : 431 436, 1950.

6) Satoyosi E, et al : Clinical manifestations and diagnostic problems of multiple sclerosis in Japan. Neurology (Minneap) 26(6, Part 2) $: 23$ $\sim 25,1976$.

7 ) Dayal VS, et al : Neurootologic studies in multiple sclerosis. Laryngoscope $76: 1798 \sim 1809$, 1966.

8) Noffsinger D, et al : Auditory and vestibular abberations in multiple sclerosis. Acta Otolaryngol (Stockh) Suppl $303: 1 \sim 63,1972$.

9 ) Grénman R : Involvement of the audiovestibular system in multiple sclerosis. An otoneurologic and audiologic study. Acta Otolaryngol(Stockh) Suppl $420: 1 \sim 95,1985$.

10) Harrison MS and Ozsahinoglu C : Positional vertigo; aetiology and clinical significance. Brain $95: 369 \sim 372,1972$.

11）徳永 修, 他: 多発性硬化症之聴覚・平衡障害. 日耳鼻 $80 ： 489 \sim 496 ， 1977$.

12) Molteni RA : Vertigo as a presenting symptom of multiple sclerosis in childhood. Am J Dis Child 131:553 554, 1977.

13) Katsarkas A : Positional nystagmus of the "central type" as an early sign of multiple sclerosis. J Otolaryngol $11: 91 \sim 93,1982$.

14）村井盛子, 福地 淳：聴覚・平衡障害を早期症状 とした多発性硬化症の一例.臨床耳科 $10: 156$ $\sim 157,1983$.

15）服部 進，他：第 8 脳神経症状で発症した多発性 硬化症の 1 例. 臨床神経 $27: 721 \sim 724 ， 1987$.

16）中川敏幸, 他 : 両側 MLF 症候群で発症した多発 性硬化症の 1 例一パルス療法前後におりる磁気共 鳴像の経時的変化について一. 神経内科 27 ： 373 376, 1987.

17）横田序一, 他：MRI にて一側小脸脚中心に病変 の認められた MS 2症例. Equilibrium Res 46 : 62, 1987.

18）馬塲完仁, 他 : 多発性硬化症疑い例の興味深い神 経耳科所見. 耳鼻臨床 $81: 493 \sim 504 ， 1988$.

19) Haughton VM, et al : CT detection of demyelinated plaques in multiple sclerosis. Am J Roentgenol 132:213 215, 1979.

$\left(\begin{array}{l}\text { 原稿採択 : 昭和63年 } 9 \text { 月 } 19 \text { 日 } \\ \text { 別刷請求先 : 小山内龍一 } \\ \text { T183 東京都府中市 武蔵台 2-6-1 } \\ \text { 東京都立神経病院神経耳科 }\end{array}\right)$

